\title{
Employee participation under German company law
}

\author{
Frank Wooldridge
}

I n the nineteenth century certain German Christian and liberal writers on political theory advocated cooperation between the owners of capital and their employees in German business entities. The first statutory provision to be influenced by the concept of the creation of committees of workers exercising particular functions was enacted in July 1891. A similar arrangement was provided for and made compulsory by the Gesetz über den väterlandische Hulfsdienst (law governing the national emergency service) of December 5, 1916. A decree was enacted on December 12, 1918 concerning wage agreements, the use of committees of ordinary and white collar workers, and the arbitration of industrial disputes (Die Verordung über Tarifvertrage Arbeiter und Angestelltenauschüsse, und Schichtung von Arbeitstreitigkeiten).

On February 15, 1922, a law was passed governing the access of representatives of workers to the works councils of German public companies. However, the Nazi retime abolished works councils and employee representation in the supervisory boards of German public companies.

\section{LEGISLATION GOVERNING THE COAL, IRON AND STEEL INDUSTRIES}

Legislation was passed in the British zone of occupation of Germany governing employee representation in the steel industry to 1947. This legislation was extended to the whole of the Federal Republic and to the coal industry by the Montan Mitbestimmungsgesetz of 1951 (BGB1 1.348) which applied to employee codetermination in the coal, iron and steel industries. It affected undertakings whose principal objects were the provision of coal and iron ore, the preparation, carbonisation, compression (Brikettierung) and alteration of such products, or the production of iron and steel. Such undertakings might take the form of a public or a private company (AG or $\mathrm{GmbH}$ ), and were required to regularly employ more than 1,000 persons.

The enactment of the statute of 1951 was followed by that of the Montan Mitbestimmungsergänzungsgesetz of 1956, which applied to iron and steel holding companies.

\section{THE WORKS COUNCILS ACTS OF 1952 AND 1972 THE DRITTELBETEILIGUNGSGESETZ (DRITTEL BG) OF 2004}

The Betreibsverfassungsgesetz (Works Councils Act) in its 1972 version contained provisions in paragraphs 87 et seq thereof which gave the works council certain rights of codetermination which were binding on the employers, and which were applicable to companies that were not operating in the coal, iron and steel industries. The relevant rights had to be exercised at the level of the supervisory board: this gave rise to criticisms on the ground that the supervisory board has limited functions and may not always be adequately provided with staff.

Paragraphs 76 and 77 of the Works Council Act in its 1952 and 1972 versions required one third of the members of the supervisory board to consist of representatives of the employees. The same situation remains, in those companies which employ at least 500 but not more than 2,000 persons, and are thus subject to the Drittelbeteilsgungsgesetz (One Third Participation Act of 2004 as amended). The latter Act has no application to companies whose main purpose is the production of coal and iron or the preparation of these materials and which are subject to the inspection by the mining authorities, and to which a quasi-paritative (or equal) system of codetermination is applicable. According to paragraph 4(3) of the DrittelbG, one third of the members of the supervisory boards of such companies should consist of representatives of the employees. Such representatives must be at least 18 years old, and have worked in the undertaking for at least one year (para 4(3) DrittelbG). They are directly elected by a secret ballot by the employees of the undertaking who have reached the age of 18 (para 5 DrittelbG).

The view has been frequently expressed that the quasiparitative approach to the composition of the supervisory board taken in the coal, iron and steel industries should be adopted in other branches of industry. The enactment of the Mitbestimmungsgesetz of 1976 has resulted in this situation coming about to a considerable extent.

The DrittelbG applies to public companies (para 1(1) DrittelbG) and limited partnerships with shares (Kommanditgesellschaften auf Aktien), paragraph 1(1) No2 DrittelbG. It is also applicable to private companies and 
registered cooperatives which regularly employ more than 500 persons. Furthermore, it applies to mutual insurance companies which regularly employ more than 500 persons and which have a supervisory role.

\section{THE MITBESTIMMUNGSGESETZ (MBG) OF 1976}

The above statute, which enacted a new quasi-paritative system of codetermination in the supervisory boards of public and private companies, limited partnerships with shares (Kommanditgesellschadften mit Aktien) and registered cooperatives (eigentragene Genossenschaften) employing more than 2,000 persons, which were not engaged in the coal, iron and steel industries, was passed by a considerable majority in the Bundestag. However, certain employers, and federations thereof, made a complaint to the Federal Constitutional Court (Bundesverfassungsgericht) contending that the new legislation was unconstitutional, and violated the guarantee of private property guaranteed in paragraph 14 of the Federal German Constitution. The Constitutional Court unequivocally rejected this complaint, finding that no such violation had taken place. It found that the German Constitution did not establish and guarantee a particular type of economic order.

The Mitbestimmingsgesetz of 1976 did not attempt to codify the law governing employee codetermination, or to modify the special rules governing coal, iron and steel companies. Certain types of undertaking were exempted from the application, as were coal, iron and steel undertakings. The 1976 Act was also made inapplicable to undertakings which directly and principally have political, confessional, charitable, educational, scientific or artistic aims, or whose objective is reporting or the expression of opinion, and to which paragraph 5(1) No 2 of the German Constitution is applicable. The latter text guarantees the freedom of the press and its expression through the medium of broadcasting and films.

The MBG is also applicable to the $\mathrm{GmbH}$ and $\mathrm{Co} \mathrm{KG}$, a type of entity which is frequently employed in Germany. It consists of a limited partnership in which a private limited liability company $(\mathrm{GmbH})$ is usually the unlimited partner and is quite often, although not necessarily, the only such partner. The unlimited partner may instead be a public company, or a registered cooperative (eigentragene Genossenschaft).

According to paragraph 4(1) of the Mitbestimmungsgesetz, if a $\mathrm{GmbH}$, (AG Aktiengesellschaft) (public company), KG auf Aktien (limited partnership with shares) or a cooperative is the personally liable partner in a limited partnership with shares, and the majority of the limited partners in this limited partnership hold the majority of the votes or shares in the undertaking of the personally liable partners, then for the purpose of the application of the Mitbestimmungsgesetz of 1976 to that partner, the employees of the limited partnership are treated as though they were employees of the personally liable partners, provided that that partner does not carry on a business employing more than 500 persons.

Dr Frank Wooldridge 